\title{
Prognostic value of serum concentration of matrix metaloproteinase- 9 in patients in acute period of spontaneous supratentorial intracerebral hemorrhage
}

\author{
A.A. Kuznietsov \\ Zaporizhzhia State Medical University, Zaporizhzhia, Ukraine
}

\begin{abstract}
Objective: to evaluate the informative value of serum concentration of matrix metalloproteinase (MMP)- 9 within the determination of the short-term prognosis in patients in the acute period of spontaneous supratentorial intracerebral hemorrhage (SSICH) on the ground of conservative treatment. Materials and methods. A prospective, cohort, comparative study was conducted in 105 patients in the acute period of SSICH on the ground of conservative treatment. The level of neurological deficit was assessed using of the Full Outline of Unresponsiveness Coma Scale, the Glasgow Coma Scale, and the National Institutes of Health Stroke Scale. The visualization of cerebral structures was performed by computed tomography. On the 1st and 5th day from the admission, laboratory blood samples were taken and then serum concentrations of MMP-9 were determined by enzyme-linked immunosorbent assay. Early neurological deterioration and unfavorable outcome of the acute period of SSICH (modified Rankin scale grade 4-6 on the 21 st day of the disease) were registered as combined clinical endpoints. Statistical processing of the results was carried out with the help of correlation analysis, logistic regression analysis, ROC-analysis. Results. Patients with unfavorable clinical course and unfavorable outcome of the acute period of SSICH had a higher serum concentration of MMP-9 on the 1st day from the admission, and this marker was directly correlated with the secondary intraventricular hemorrhage volume $(R=0.40, p<0.01)$ and total volume of intracranial hemorrhage $(R=0.29, p<0.01)$. It was determined that the assessment of serum MMP-9 concentration along with neuroimaging indicators (midline shift severity, secondary intraventricular hemorrhage volume) as part of the developed multi-predictor logistic regression model allows to verify individual risk of early neurological deterioration (AUC \pm SE ( $95 \%$ confidence interval) $=0.93 \pm 0.03(0.86-0.97), p<0.0001)$. Conclusion. Serum MMP-9 levels in patients with SSICH on the 1 st day from admission is an informative additional parameter for prediction of early neurological deterioration on the ground of conservative treatment.
\end{abstract}

Key words: intracerebral hemorrhage, matrix metalloproteinase-9, prognosis.

\section{Introduction}

Despite significant achievements in fundamental neuroscience, clinical angioneurology and neurosurgery, cerebral hemorrhagic stroke remains one of the most complicated problems of modern medicine. It has a strong lead in the structure of causes of mortality and disability in adults in most countries. Spontaneous supratentorial intracerebral hemorrhage $(\mathrm{SSICH})$ is the most common form of cerebral hemorrhagic stroke [1, 2]. Important measures aimed to improve the provision of care to patients with SSICH consist in the development of informative criteria for the determination of the short-term prognosis for choosing the optimal treatment tactics. Taking the above-mentioned in consideration, it is very appropriate to search for biomarkers that are associated with the risk of unfavorable outcome of the acute period of the disease on the ground of conservative therapy $[3,4]$.

Proinflammatory activation plays a leading role in the implementation of mechanisms of secondary damage of cerebral structures in patients with SSICH [5]. However, intracerebral hematoma initiates the synthesis and active secretion of a wide range of proinflammatory cytokines, as well as proteolytic enzymes, one of which is matrix metalloproteinase (MMP)-9. The modern concept of views on the modulation effect of MMP-9 on the course of acute intracerebral hemorrhage contains the duality of MMP-9 effects. It depends on the phase of the disease [6]. Thus, in the most acute period of intracerebral hemorrhage, MMP-9 has a neurotoxic effect, namely: when it participates in the degradation of the extracellular matrix, MMP-9 leads to the destruction of the endothelial basal plate, which increases the permeability of the blood-brain barrier and promotes cerebral edema $[4,7,8]$. Subsequently, MMP-9 stimulates angiogenesis, vascular remodeling, cell migration and phagocytosis and thus implements the mechanisms of sanogenesis $[6,9]$. However, the study of the prognostic value of MMP-9 in the serum in patients with spontaneous intracerebral hemorrhage is insufficient. Scientific literature gives few information and a rather limited number of single studies in this field. Most of them contain the results of the relation of serum concentration of MMP-9 with the severity of cerebral lesions and the level of neurological deficit $[10,11]$. There are no stud- ies related to the informative concentration of MMP-9 in the verification of short-term prognosis, in particular in terms of assessment of the feasibility of detection of this indicator in clinical practice for the prediction of the outcome of the acute period of the disease on the ground of conservative therapy.

Objective: to evaluate the informative value of serum concentration of MMP-9 within the determination of the short-term prognosis in patients in the acute period of SSICH on the ground of conservative treatment.

\section{Materials and methods}

In order to achieve the goal, a prospective, cohort, comparative study was conducted at non-commercial institution «City Hospital No.6» of Zaporizhzhia Municipal Council. 105 patients (55 men and 50 women, aged $66(59 ; 75)$ with hemispheric hemorrhagic stroke participated in the study. The inclusion criteria were: 1) spontaneous (hypertensive) supratentorial intracerebral hemorrhage; 2) admission within the first 24 hours upon the onset of the disease; 3 ) signed consent form to participate in the study.

The diagnosis was set on the basis of the results of complex clinical and neuroimaging study. The assessment of the neurological deficit level was conducted considering the course of the acute period of the disease with the help of Full Outline of UnResponsiveness (FOUR) Scale, Glasgow Coma Scale (GCS) and National Institutes of Health Stroke (NIHSS) Scale. Cerebral structures were visualized with the help of computed tomography, namely "Siemens Somatom Spirit» (Germany) or "Toshiba Asteion" (Japan).

The intracerebral hemorrhage volume (ICHV) was counted with the help of ellipsoid formula. Midline shift (MS) of cerebral structures was considered as the mean displacement of the septum pellucidum and pineal gland. Secondary intraventricular hemorrhage volume (SIVHV) was assessed with the help of the following formula:

$$
S I V H V=e^{I V H S / 5} \text {, }
$$

where IVHS is the total score value in accordance with Intraventricular Hemorrhage Scale. 
The total intracranial hemorrhage volume (TICHV) was determined by the sum of ICHV and SIVHV.

All patients were also examined by a neurosurgeon.

The exclusion criteria were: 1 ) acute cerebrovascular disorders in the anamnesis; 2) intracerebral hemorrhage due to cerebral infarction, brain tumor or anticoagulant therapy; 3 ) acute focal lesion of cerebral structures of other genesis and localization; 4) indications for surgical treatment appointed by a neurosurgeon; 5) diseases of inflammatory genesis (including infectious) upon hospitalization; 6) malignant neoplasms; 7) decompensated somatic pathology.

Within 24 hours from admission, all patients were taken blood samples in order to determine the serum concentration of MMP-9. Laboratory blood samples were taken in 72 patients on the 5 th day after hospitalization. The content of MMP-9 in the serum was determined by enzyme-linked immunosorbent assay using sets of reagents "Elabscience » (USA) on the enzyme-linked immunosorbent complex «ImmunoChem-2100» (USA) at the clinical diagnostic laboratory of the University Clinic of Zaporizhzhia State Medical University (total quantity of measurements is 177).

On the basis of the results of the examination by a neurosurgeon, a conservative therapy was chosen as the optimal treatment tactic. Patients were treated in accordance with the unified clinical protocol of specialized care for patients with spontaneous intracerebral hemorrhage, approved by the Ministry of Health of Ukraine of 17.04.2014 № 275. In the course of the acute period of SSICH, cases of early neurological deterioration (END) were registered. They were accompanied by the increase of the severity of cerebral syndrome in the form of a decrease in total score on the FOUR coma scale $\geq 2$ and/or deepening neurological deficit in the form of increasing of total NIHSS score $\geq 4$ and/or lethal outcome within 48 hours from admission. The outcome of the acute period of SSICH was determined on the 21st day of the disease using a modified Rankin Scale (mRS). An unfavorable outcome was determined by the value of 4-6 points per mRS - combined clinical endpoint, which integrates lethal outcome ( 6 points per $m R S$ ) and unfavorable functional outcome in the form of profound disability (4-5 points per $\mathrm{mRS}$ ). Patients with confirmed aneurysm or arteriovenous malformation of cerebral vessels, as well as in the case of verification of extracerebral cause of death (defined according to the results of autopsy) were excluded from the study.

Statistical assessment of the obtained results was performed with the help of the programs «Statistica 13.0» («StatSoft Inc.», USA, series number JPZ804I382130ARCN10J) and «MedCalc» (version 18.2.1). As the distribution of most of the studied indexes were different from normal in accordance with the Shapiro - Wilk criterion, descriptive statistics are presented in the form of median and interquartile range. Intergroup differences were assessed by the Mann Whitney test and Wilcoxon test. Correlation analysis with the calculation of Spearman's rank correlation coefficient, logistic regression analysis, ROC-analysis were used. Indicators of sensitivity, specificity and relative risk (RR) were determined. The significance level $p<0.05$ was considered critical for rejecting the null hypotheses.

\section{Results}

In the general cohort of patients, the values of clinical and neuroimaging parameters upon the inclusion in the study were as follows: FOUR score $-16(14 ; 16)$, GCS score $-13(12 ; 15)$, NIHSS score - $14(10 ; 18)$, ICHV $-11.7(5.6 ; 25.3) \mathrm{mL}, \mathrm{MS}-2.5(0.0 ; 4.0)$ $\mathrm{mm}$, SIVHV $-6.0(0.0 ; 16.4) \mathrm{mL}$, TICHV $-20.3(10.1 ; 49.4) \mathrm{mL}$. The content of MMP-9 in the serum of patients with $\mathrm{SSICH}$ on the 1 st day after hospitalization constituted $72.0(39.9 ; 107.8) \mathrm{pg} / \mathrm{mL}$.

On the basis of the correlation analysis, it was determined that the serum concentration of MMP-9 is associated with SIVHV ( $R=0.39$, $p<0.01)$ and TICHV $(R=0.29, p<0.01)$. The analysis of the content of MMP-9 in the blood serum in dependence to the severity of the lesion of cerebral structures was also performed. Thus, the level of serum MMP-9 concentration in the group of patients with $\mathrm{ICHV}>30 \mathrm{ml}$ $(n=25)$ was $18.0 \%$ higher $(82.0(66.6 ; 136.9)$ versus $69.5(38.7 ; 94.9)$ $\mathrm{pg} / \mathrm{mL}$ in the group of patients with ICHV $\leq 30 \mathrm{ml}, \mathrm{p}=0.0152)$; in the cohort of patients with SIVHV $>15 \mathrm{~mL}(\mathrm{n}=28)$ - it was $66.0 \%$ higher $(100.3(80.5 ; 139.4)$ versus $64.3(35.1 ; 85.7) \mathrm{pg} / \mathrm{mL}$ in patients with
SIVHV $\leq 15 \mathrm{~mL}, \mathrm{p}<0.0001)$; in the group of patients with TICHV $>40 \mathrm{~mL}$ $(n=30)$ - it was $50.5 \%$ higher $(99.9(73.6 ; 136.5)$ versus $66.6(36.8$; 87.6) $\mathrm{pg} / \mathrm{mL}$ in patients with $\mathrm{TICHV} \leq 40 \mathrm{~mL}, \mathrm{p}<0.0001)$.

Neurological deterioration within 48 hours from the moment of hospitalization was recorded in $22(21.0 \%)$ patients. On the 1st day from admission this subcohort of patients significantly differed from the group of patients without END in the following parameters: FOUR score $(14(12 ; 15)$ versus $16(15 ; 16), \mathrm{p}<0.0001)$, GCS score $(12$ $(9 ; 13)$ versus $14(12 ; 15), \mathrm{p}=0.0009)$, NIHSS score $(17(15 ; 21)$ versus 14 (10; 17), $\mathrm{p}=0.0009), \mathrm{ICHV}(49.8(20.9 ; 63.6)$ versus $10.6(5.1 ; 16.8) \mathrm{mL}$, $\mathrm{p}=0.0004)$, MS $(4.5(2.5 ; 7.5)$ versus $1.5(0.0 ; 3.0) \mathrm{mm}, \mathrm{p}=0.0002)$, SIVHV $(30.0(17.4 ; 52.1)$ versus $3,3(0.0 ; 11.0) \mathrm{mL}, \mathrm{p}=0.0002), \mathrm{TICHV}(82.4$ (55.5; $106.0)$ versus $15.5(8.1 ; 28.9) \mathrm{mL}, \mathrm{p}<0.0001)$, MMP-9 content in blood serum $(115.9(99.8 ; 144.6)$ versus $67,9(36.8 ; 81.7) \mathrm{pg} / \mathrm{mL}, \mathrm{p}<0.0001)$.

In accordance with the univariate logistic regression analysis, the risk of END in patients with SSICH is determined by FOUR score (odds ratio $(\mathrm{OR})(95 \%$ confidence interval $-\mathrm{Cl})=0.546(0.400-0.747)$, $\mathrm{p}=0.0001)$, GCS score (OR $(95 \% \mathrm{Cl})=0.635(0.496-0.814), \mathrm{p}=0.0003)$, NIHSS score $(\mathrm{OR}(95 \% \mathrm{Cl})=1.187(1.064-1.324), \mathrm{p}=0.0021)$, ICHV (OR $(95 \% \mathrm{Cl})=1.054(1.028-1.080), \mathrm{p}<0.0001)$, MS $(\mathrm{OR}(95 \% \mathrm{Cl})=1.820$ (1.388-2.387), $p<0.0001)$, SIVHV (OR (95\% Cl)=1.093 (1.051-1.137), $\mathrm{p}<0.0001), \operatorname{TICHV}(\mathrm{OR}(95 \% \mathrm{Cl})=1.054(1.032-1.077), \mathrm{p}<0.0001)$, MMP9 concentration in serum $(\mathrm{OR}(95 \% \mathrm{Cl})=1.028(1.015-1.041), \mathrm{p}<0.0001)$. In accordance with the results of multiple logistic regression analysis, the following parameters confirmed an independent association with END risk: MS $(\mathrm{OR}(95 \% \mathrm{Cl})=1.597(1.134-2.248), \mathrm{p}=0.0074)$, SIVHV (OR $(95 \% \mathrm{Cl})=1.061(1.021-1.103), \mathrm{p}=0.0026)$; MMP-9 concentration in se$\operatorname{rum}(\mathrm{OR}(95 \% \mathrm{Cl})=1.020(1.001-1.039), \mathrm{p}=0.0384)$.

In order to predict END in patients with $\mathrm{SSICH}$, the above mentioned indicators were integrated into a multi-predictor mathematical model, which has the following form of a binary logistic regression equation:

$$
\beta=-5,616+0,468 \cdot \text { Pred }_{1}+0,060 \cdot \text { Pred }_{2}+0,019 \cdot \text { Pred }_{3^{\prime}}
$$

where $-5,616$ - intercept $\left(\beta_{0}\right)$, Pred 1 - MS severity $(\mathrm{mm})$, Pred $_{2}$ SIVHV (mL), Pred $_{3}$ - MMP-9 concentration in serum $(\mathrm{pg} / \mathrm{mL})$.

On the basis of the ROC-analysis, the threshold value of $\beta$ $(>-1,108)$ was determined, which is an integral predictor of neurological deterioration in patients with $\mathrm{SSICH}$ within 48 hours from the moment of hospitalization (sensitivity $-81.8 \%$, specificity - 90.4\%). The assessment of the informative value and that of the quality of the developed mathematical model was carried out on the basis of the following indicators: the level of significance of Hosmer-Lemeshow test $\mathrm{p}=0.7990$; forecasting accuracy (proportion of truly positive and truly negative results) - 90.5\%; AUC \pm SE (95\% $\mathrm{Cl})=0.93 \pm 0.03$ (0.86-0.97), $\mathrm{p}<0.0001$ (fig. 1).

Early neurological deterioration in the group of patients with a value of $\beta>-1,108$ ( $n=26)$ was found in $69.2 \%$ of cases against only $5.1 \%$ in the cohort of patients with a value of $\beta<-1.108$ (RR $(95 \%$ $\mathrm{Cl})=13.67(5.09-36.75), \mathrm{p}<0.0001)$.

It was determined that the developed model of multiple logistic regression is characterized by a higher value of AUC in comparison with separate predictors which are part of it (fig. 2).

Unfavorable outcome of the acute period of SSICH in the form of 4-6 points value of $\mathrm{mRS}$ on the 21st day of the disease was registered in 61 (58.1\%) patients. Unfavorable functional outcome in the form of 4-5 points of mRS (72.1\%) dominated in the structure of the mentioned combined clinical endpoint. The proportion of lethal outcome during the acute period of the disease was $27.9 \%$. The analysis of serum concentration of MMP-9 in relation with the outcome of the acute period of the disease was conducted on the ground of conservative therapy. It was determined that patients who had a combined clinical endpoint, on the 1st day from admission had different content of MMP-9 in the serum $(77.9(67.0 ; 118.8)$ versus $41.1(30.6 ; 88.5) \mathrm{pg} /$ $\mathrm{mL}, \mathrm{p}=0.0004)$. Patients with the lethal outcome of the acute period of $\mathrm{SSICH}$, on the 1st day after hospitalization also had different MMP9 concentration in serum $(122.7(82.9 ; 147.2)$ versus $68.8(37.7 ; 89.6)$ $\mathrm{pg} / \mathrm{mL}, \mathrm{p}<0.0001)$. When comparing groups of patients in relation to the functional outcome of the acute period of SSICH (4-5 points per $\mathrm{mRS}$ and $0-3$ points per $\mathrm{mRS}$ ), differences in the initial content of MMP-9 were determined: $70.9(61.9 ; 91.5)$ versus $41.1(30.6 ; 88.5) \mathrm{pg} /$ 
Figure $1 \quad$ ROC-curve of the developed multi-predictor mathematical model for the determination of individual risk of early clinical and neurologic deterioration in patients with $\mathrm{SSICH}$, which considers initial neuroimaging indicators (MS severity, SIVHV) and MMP-9 concentration in serum on the 1st day from admission

BETA

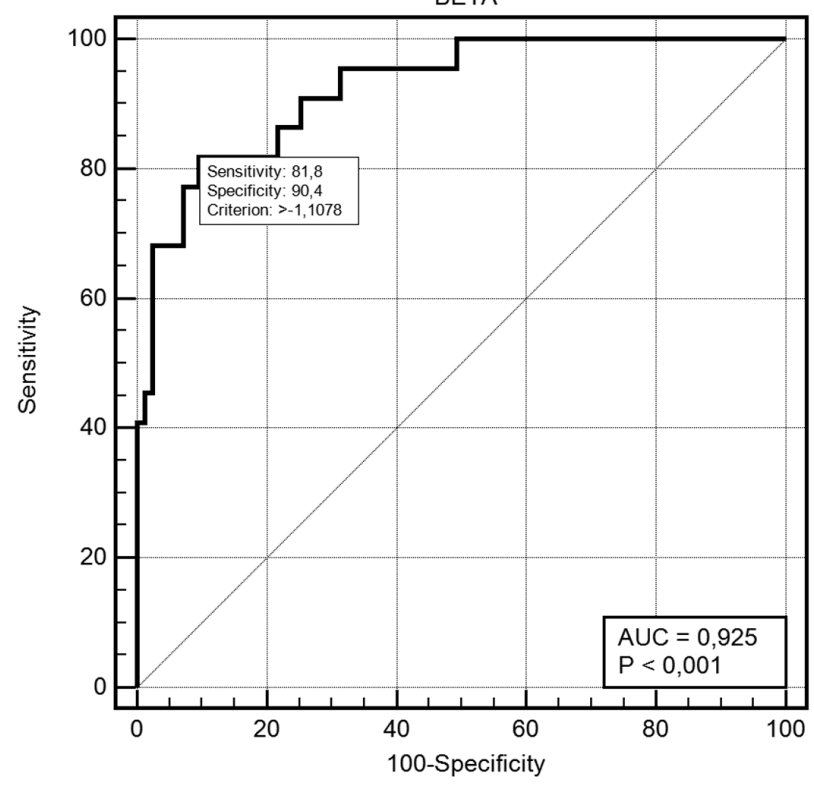

Figure 2 Comparative analysis of the informative value of the developed model of multiple logistic regression and separate predictors that are part of it, in the process of determination of the individual risk of early neurological deterioration in patients with $\mathrm{SSICH}$

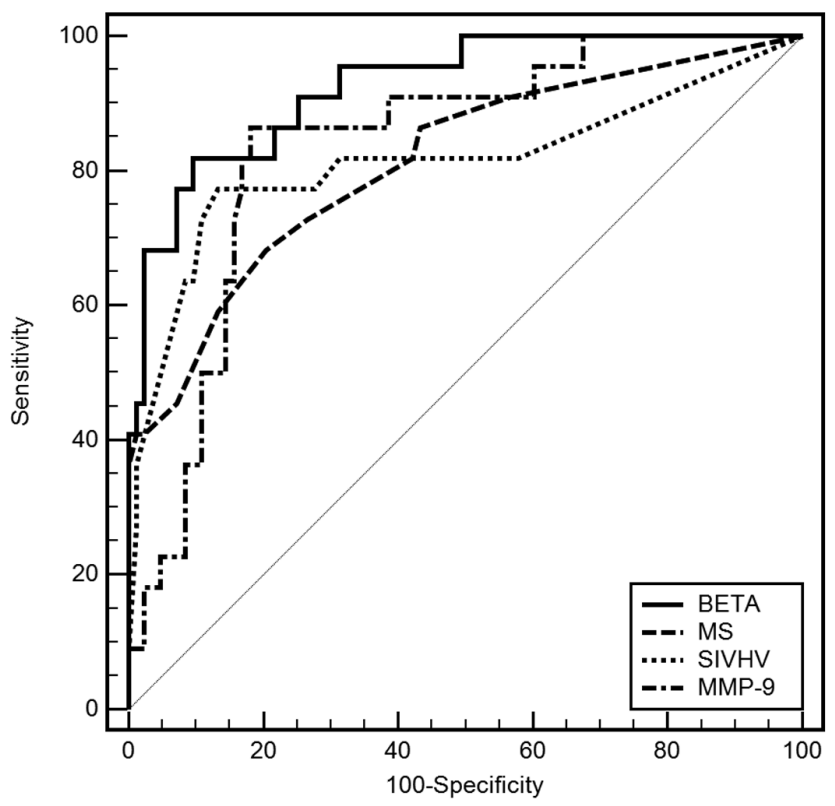

$\mathrm{mL}$, respectively, $\mathrm{p}=0.0167)$. However, in accordance with the results of multiple logistic regression analysis, the MMP-9 concentration in patients with $\mathrm{SSICH}$ on the 1st day after hospitalization was not included to multi-predictor logistic regression models as for the prediction of the acute period outcome of the disease.

The determination of MMP-9 concentration in serum on the 5th day after hospitalization was performed in 72 patients $(38$ men and 34 women, aged $66(60 ; 74)$ years). Clinical and neuroimaging characteristics of this subcohort at the moment of their inclusion in the study were as follows: FOUR score - $16(14 ; 16)$, GCS score - $13(12 ; 15)$, NIHSS score $-14(10 ; 18)$, ICHV $-11.2(5.0 ; 22.3) \mathrm{mL}, \mathrm{MS}-2.0(0.0 ; 3.5)$ $\mathrm{mm}$, SIVHV - $4.1(0.0 ; 13.5) \mathrm{mL}$, TICHV $-18.2(8.6 ; 37.7) \mathrm{mL}$. The con- tent of MMP-9 in the serum of patients with SSICH on the 1st day after hospitalization was $72.4(42.1 ; 102.4) \mathrm{pg} / \mathrm{mL}$, on the 5 th day -134.6 $(105.3 ; 166.5) \mathrm{pg} / \mathrm{mL}$. On the basis of a correlation analysis, it was determined that the serum concentration of MMP-9 on the 5th day after hospitalization is associated with the initial content of MMP-9 in the serum ( $R=0.29, p<0.01)$, as well as TICHV $(R=0.23, p<0.01)$. Thus, on the 5th day after hospitalization the group of patients with TICHV $>40 \mathrm{ml}$ $(n=17)$ demonstrated a $29.0 \%$ higher median serum concentration of MMP-9 in comparison with the subcohort of patients with TICHV $\leq 40 \mathrm{ml}$ (166.3 $(129.9 ; 172.1)$ versus $128.9(99.1 ; 148.3) \mathrm{pg} / \mathrm{mL}, \mathrm{p}=0.0365)$.

Early neurological deterioration occurred in 14 (19.4\%) patients. This group of patients on the 5th day after hospitalization was significantly different from the group of patients without END in the content of MMP-9 in the serum $(167.3(134.1 ; 188.8)$ versus 128.1 (100.9; 148.5) $\mathrm{pg} / \mathrm{mL}, \mathrm{p}=0.0160$ ). Unfavorable outcome of SSICH acute period in the form of 4-6 points value of mRS on the 21st day of the disease was registered in 41 (56.9\%) patients. The cases of unfavorable functional outcome in the form of $4-5$ points of mRS (82.9\%) dominated in the structure of the mentioned combined clinical endpoint. The proportion of lethal outcome during the acute period of the disease constituted $17.1 \%$. On the 5 th day after hospitalization, the group of patients with unfavorable outcome of SSICH acute period also had a high MMP-9 concentration in serum $(145.8(116.8 ; 170.7)$ versus 118.2 $(86.3 ; 139.8) \mathrm{pg} / \mathrm{mL}, \mathrm{p}=0.0063)$. Thus, on the 5 th day after hospitalization, a statistically significant elevation of serum MMP-9 concentration was determined not only in the general cohort of patients (from $72.4(42.1 ; 102.4)$ to $134.6(105.3 ; 166.5) \mathrm{pg} / \mathrm{mL}, \mathrm{p}<0.0001)$, but also in subgroups of patients with different variants of the course and outcome of the acute period of the disease, namely in the subcohort with END (from $104.8(96.6 ; 130.1)$ to $167.3(134.1 ; 188.8) \mathrm{pg} / \mathrm{mL}, \mathrm{p}=0.0166)$, without END (from $68.4(38.2 ; 84.8)$ to $128.1(100.9 ; 148.5) \mathrm{pg} / \mathrm{mL}$, $\mathrm{p}<0.0001$ ), in a subcohort with an unfavorable outcome (from 74.7 $(62.0 ; 109.1)$ to $145.8(116.8 ; 170.7) \mathrm{pg} / \mathrm{mL}, \mathrm{p}<0.0001)$ and in a subcohort with favorable outcome of the acute period of the disease (from $64.3(31.4 ; 93.8)$ to $118.2(86.3 ; 139.8) \mathrm{pg} / \mathrm{mL}, \mathrm{p}<0.0001)$.

\section{Discussion}

In accordance with the results of the study, in the 1st day after hospitalization patients with unfavorable course (END) and unfavorable outcome of SSICH acute period (4-6 points of $\mathrm{mRS}$ ) had significantly higher MMP-9 concentration in serum. This value was directly correlated with the initial severity of lesions of cerebral structures. It was determined that regardless of the initial level of neurological deficit and the course of the acute period of the disease, MMP-9 concentration in serum elevates within 5 days. The obtained data are consistent with the studies of other researchers $[6,11]$. This study gave details related to the structure of interrelation between MMP-9 in serum and quantitative neuroimaging parameters. Namely, it was shown that SIVHV affects the content of MMP9 in the serum in patients with SSICH on the 1st day after hospitalization.

On the basis of a multiple logistic regression analysis, an independent association was found between MMP-9 concentration of serum and END risk, which led to the development of a highly sensitive multi-predictor model for END prediction in the course of conservative therapy that takes into account the set of neuroimaging indicators (MS, SIVHV) and MMP-9 concentration of serum in patients with SSICH on the 1st day after hospitalization. This model is characterized by a $90.5 \%$ accuracy (AUC $=0.93, p<0.0001$ ). On the basis of the comparative ROCanalysis, it was found that the developed model of multiple logistic regression has a higher value of AUC in comparison with individual predictors which are part of it. Thus, the assessment of the content of MMP-9 in the serum of patients with SSICH on the 1st day after hospitalization helps to increase the accuracy of neuroimaging verification of the prognosis of the acute period of the disease. It is also possible to use the developed multi-predictor model in order to calculate the quantitative END risk indicator in the course of conservative therapy, which is measured in the range from 0 (very low probability) to 1 (extremely high probability) and is determined by the following formula:

$$
y=\exp (\beta) /[1+\exp (\beta)] \text {, }
$$

where $y$ is the probability of END in the course of conservative therapy, $\beta$ is the value of the binary logistic regression equation. 
The identified correlation between the content of MMP-9 in the serum and the risk of END on the 1st day after hospitalization may be due to the fact that MMP-9 increases the permeability of the bloodbrain barrier and thus increases cerebral edema in the alternative phase of intracerebral hemorrhage [6-8]. The veracity of this conclusion is also evidenced by the results of a study conducted by Y. Shi et al. (2021), which showed that patients with hematoma progression within 6 hours from the onset of the disease had higher serum concentrations of MMP-9 [12]. However, according to multiple logistic regression analysis, no independent correlation was found between the content of MMP-9 in the serum of patients on the 1st day after hospitalization and the risk of unfavorable outcome of the acute period of the disease, most likely due to variable implementation of a wide range of long term effects of MMP-9 in the course of SSICH.

\section{Conclusions}

1. MMP-9 concentration in the serum of patients with SSICH correlates with the severity of damage to cerebral structures and is an informative additional indicator for the prediction of the course of the acute period of the disease on the ground of conservative therapy.

2. The evaluation of MMP-9 concentration in serum along with neuroimaging indicators (MS severity, SIVHV) as a part of the developed multi-predictor logistic regression model allows to define individual risk of early clinical and neurological deterioration on the ground of conservative therapy. The accuracy is $90.5 \%$ (AUC \pm SE $(95 \% \mathrm{Cl})=0.93 \pm 0.03(0.86-0.97), \mathrm{p}<0.0001)$.

The prospective goal of research is to develop a differentiated approach to the choice of optimal treatment tactics in patients with $\mathrm{SSICH}$, taking into account the individual risk of early neurological deterioration.

Conflict of interest: the author declares no conflict of interests.

\section{References:}

1. Pinho J., Costa A.S., Araújo J.M. et al. (2019) Intracerebral hemorrhage outcome: A comprehensive update. J. Neurol. Sci., 398: 54-66. https://doi.org/10.1016/j.jns.2019.01.013

2. de Oliveira Manoel A.L. (2020) Surgery for spontaneous intracerebral hemorrhage. Crit. Care, 24(1): 45. doi:10.1186/s13054-020-2749-2

3. Hostettler I.C., Seiffge D.J., Werring D.J. (2019) Intracerebral hemorrhage: an update on diagnosis and treatment. Exp. Rev. Neurother., 19(7):679-694. https://doi.org/10.1080/14737175.2019.1623671

4. Senn R., Elkind M.S., Montaner J.etal. (2014) Potential role of blood biomarkers in the management of nontraumatic intracerebral hemorrhage. Cerebrovasc. Dis. (Basel, Switzerland), 38(6):395-409. https://doi.org/10.1159/000366470

5. Bernstein J.E., Savla P., Dong F. et al. (2018) Inflammatory Markers and Severity of Intracerebral Hemorrhage. Cureus, 10(10): e3529. https://doi.org/10.7759/cureus.3529

6. Chang J.J., Emanuel B.A.,MackW.J. et al. (2014) Matrix metalloproteinase-9: dual role and temporal profile in intracerebral hemorrhage.J. Stroke Cerebrovasc. Dis., 23(10):2498-2505. https://doi. org/10.1016/j.jstrokecerebrovasdis.2014.07.005

7. Yong V.W. (2005) Metalloproteinases: mediators of pathology and regeneration in the CNS. Nature reviews. Neurosci., 6(12): 931-944. https://doi.org/10.1038/nrn1807

8. Cuadrado E., Rosell A., Penalba A. et al. (2009) Vascular MMP-9/TIMP-2 and neuronal MMP-10 upregulation in human brain after stroke: a combined laser microdissection and protein array study. J.Prot. Res., 8(6): 3191-3197.https://doi.org/10.1021/pr801012x

9. LeiC., LinS., Zhang C. etal. (2013) Activation of cerebral recovery by matrix metalloproteinase- 9 after intracerebral hemorrhage. Neurosci., 230: 86-93. https://doi.org/10.1016/j.neuroscience.2012.11.008

10. Abilleira S., Montaner J., Molina C.A. et al. (2003) Matrix metalloproteinase-9 concentration after spontaneous intracerebral hemorrhage. J. Neurosurg., 99(1): 65-70. https://doi.org/10.3171/ jns.2003.99.1.0065

\section{Information about the author:}

Kuznietsov Anton A. - Associate Professor on the of Nervous Diseases Department of the Zaporizhzhia State Medical University, Zaporizhzhia, Ukraine. ORCID 0000-0002-6118-9682

\section{Address for correspondence:}

Anton Kuznietsov

69035, Zaporizhzhia, Maiakovskyi ave., 26

E-mail: titus3.05@gmail.com
11. Petrovska-Cvetkovska D., Dolnenec-Baneva N., NikodijevikD.,Chepreganova-ChangovskaT.(2014) Correlativestudy between serum matrix metalloproteinase-9 values and neurologic deficitin acute, primary, supratentorial, intracerebral haemorrhage. Prilozi. (Makedonska akademija na naukite i umetnostite. Oddelenie za medicinski nauki, 35(2): 39-44. https://doi.org/10.2478/ prilozi-2014-0005

12. ShiY., Fan X., LiG. et al. (2021) Association of Serum Dystroglycan, MMP-2/9 and AQP-4 with Haematoma Expansion in Patients with Intracerebral Haemorrhage. Neuropsych. Dis. Treatment, 17:11-18. https://doi.org/10.2147/NDT.S283016

\section{Прогностична цінність}

\section{сироваткової концентрації}

матриксної металопротеїнази-9

у пацієнтів у гострий період

\section{спонтанного супратенторіального}

\section{внутрішньомозкового крововиливу}

\section{А.А. Кузнєцов}

Запорізький державний медичний університет, Запоріжжя, Україна

Анотація. Мета - оцінити інформативність сироваткової концентрації матриксної металопротеїнази (ММП)-9 у визначенні короткострокового прогнозу у пацієнтів у гострий період спонтанного супратенторіального внутрішньомозкового крововиливу (ССВМК) на тлі консервативної терапії. Об'єкт і методи дослідження. Проведено проспективне когортне порівняльне дослідження за участю 105 пацієнтів у гострий період ССВМК на тлі консервативної терапії. Оцінку рівня неврологічного дефіциту здійснювали за шкалою коми Full Outline of UnResponsiveness, шкалою коми Глазго та шкалою інсульту Національних інститутів здоров'я США. Візуалізацію церебральних структур здійснювали методом комп'ютерної томографії. У 1-шу та на 5-ту добу з моменту госпіталізації проводили забір лабораторних зразків крові з подальшим визначенням сироваткових концентрацій ММП-9 методом імуноферментного аналізу. У якості комбінованих клінічних кінцевих точок реєстрували раннє клініконеврологічне погіршення та несприятливий вихід гострого періоду CСВМK (4-6 балів за модифікованою шкалою Ренкіна на 21-шу добу захворювання). Статистичну обробку результатів здійснювали інструментами кореляційного аналізу, логістичного регресійного аналізу, ROC-аналізу. Результати. Пацієнти з несприятливими варіантами перебігу та виходу гострого періоду ССВМК відрізнялися більш високою сироватковою концентрацією ММП-9 в 1-шу добу з моменту госпіталізації, при цьому цей показник прямо корелював з обсягом вторинного внутрішньошлуночкового крововиливу $(R=0,40, p<0,01)$ та загальним обсягом інтракраніальної геморагії $(\mathrm{R}=0,29, \mathrm{p}<0,01)$. Встановлено, що оцінка вмісту ММП-9 в сироватці крові разом із нейровізуалізаційними показниками (вираженість латеральної дислокації серединних структур мозку, обсяг вторинного внутрішньошлуночкового крововиливу) у складі розробленої мультипредикторної логістичної регресійної моделі дозволяє визначати індивідуальний ризик раннього клініко-неврологічного погіршення з точністю 90,5\% (AUC \pm SE (95\% довірчий інтервал) $=0,93 \pm 0,03(0,86-0,97), \mathrm{p}<0,0001)$. Висновок. Вміст ММП-9 в сироватці крові пацієнтів із ССВМК в 1-шу добу з моменту госпіталізації $\epsilon$ інформативним додатковим показником для прогнозування раннього клініко-неврологічного погіршення на тлі консервативної терапії.

Ключові слова: внутрішньомозковий крововилив, матриксна металопротеїназа-9, прогноз.

\section{Відомості про автора:}

Кузнєцов Антон Анатолійович — кандидат медичних наук, доцент кафедри нервових хвороб Запорізького державного медичного університету, Запоріжжя, Україна. ORCID 0000-0002-6118-9682

Адреса для кореспонденції:

Кузнєцов Антон Анатолійович

69035, Запоріжжя, пр. Маяковського, 26

E-mail: titus3.05@gmail.com 